\title{
PENGEMBANGAN DESAIN PEMBELAJARAN MODEL ADDIE MATA PELAJARAN BAHASA INGGRIS
}

\section{Puji Astuti}

Sekolah Tinggi Ilmu Kesehatan Bina Husada Palembang, Indonesia

E-mail: astuti_fuji22@yahoo.com

\section{Diterima:}

10 Desember

2021

Direvisi:

14 Desember

2021

Disetujui:

15 Desember

2021

\section{Abstrak}

Latar belakang: Pengembangan perangkat pembelajaran yang sesuai dengan materi, kebutuhan siswa, dan memuat hal yang berkaitan langsung dengan aktivitas pembelajaran sangatlah diperlukan. Untuk itu diperlukan suatu perubahan dalam mendesain perangkat pembelajaran yaitu dengan menerapkan salah satu model pembelajaran sebagai upaya pencapaian dan penguasaan kompetensi siswa. Tujuan : Tujuan penelitian pengembangan ini menghasilkan produk berupa rencana pelaksanaan pembelajaran model Analisis Desain Develop Implementasi Evaluasi (ADDIE) mata pelajaran bahasa Inggris yang teruji validitas, praktikalitas, dan efektifitasnya serta memiliki dampak terhadap hasil belajar Bahasa Inggris siswa di MTs Subulussalam Kayuagung. Metode: Penelitian ini menggunakan Menggunakan desain penelitian pengembangan yaitu suatu proses dalam mengembangkan dan validasi produk melalui beberapa tahap. Pertama, self evaluation meliputi analisis siswa, materi, dan tahap melakukan perancangan perangkat pembelajaran model Analisis Desain Develop Implementasi Evaluasi (ADDIE). Kedua, melakukan uji validasi produk kepada expert review dan one-to-one. Ketiga, uji validasi produk kepada Small Group. Produk yang telah dihasilkan berdasarkan uji validasi oleh expert, one-to-one, dan small group selanjutnya digunakan pada subjek penelitian yang sebenarnya atau field test. Hasil: Produk yang diberikan pada field test merupakan produk yang telah memenuhi standar validitas, kepraktisan dan keefektifan. Kesimpulan: Penelitian ini menghasilkan rencana pelaksanaan pembelajaran model Analisis Desain Develop Implementasi Evaluasi (ADDIE) mata pelajaran bahasa Inggris yang teruji validitas, praktikalitas, dan efektifitasnya dan memiliki dampak dalam meningkatkan hasil belajar bahasa Inggris siswa di MTs Subulussalam Kayuagung.

Kata kunci: Pengembangan, desain pembelajaran, model

\section{ADDIE}

\section{Abstract}

Background: The development of learning tools that are in accordance with the material, student needs, and contains matters directly related to learning activities is very necessary. For this reason, a change is needed in designing learning devices, namely by applying one of the learning models as an effort to achieve and master student competencies. Purpose : The purpose of this development research is to produce a product in the form of a learning implementation plan for the 
ADDIE model of English subjects that has been tested for validity, practicality, and effectiveness and has an impact on students' English learning outcomes at MTs Subulussalam Kayuagung. Methods: Using research development design, which is a process in developing and validating products through several stages. First, self-evaluation includes student analysis, material, and the stage of designing ADDIE model learning devices. Second, conducting product validation tests for expert reviews and one-to-one. Third, test product validation to the Small Group. Products that have been produced based on validation tests by experts, one-to-one, and small groups are then used on actual research subjects or field tests. Results: The product given in the field test is a product that has met the standards of validity, practicality and effectiveness. Conclusion: This study resulted in a learning implementation plan for the ADDIE model of English subjects that was tested for validity, practicality, and effectiveness and had an impact on improving students' English learning outcomes at MTs Subulussalam Kayuagung.

Keywords: Development, learning design, ADDIE model

\section{Pendahuluan}

Agar proses pembelajaran dapat berjalan dengan efektif dan efisien serta dapat mencapai tujuan yang dikehendaki, proses pembelajaran perlu direncanakan, didesain, dilaksanakan, dinilai, dan diawasi agar dapat terlaksana secara efektif dan efisien. Adanya perkembangan teknologi dan informasi dalam dunia pendidikan seharusnya memberikan kemudahan terhadap proses pembelajaran. Hal ini dikarenakan dalam proses pembelajaran akan terjadi penyampaian informasi, dimana dalam penyampaian informasi tersebut seorang pendidik dapat menggunakan alat-alat yang disebut perangkat pembelajaran dan juga memanfaatkan media pembelajaran. Implementasi pendekatan pembelajaran yang berpusat pada peserta didik secara tepat akan membawa dampak pada meninggkatanya motivasi belajar, semakin menguat daya pemahaman, semakin mendalam pengertian terhadap ilmu pengetahuan yang dipelajari, dan semakin positif sikap peserta didik terhadap mata pelajaran yang diajarkan (Yaumi, 2017). Pembelajaran adalah proses intraksi peserta didik dengan pendidik dan sumber belajar pada suatu lingkungan belajar (Hanafy, 2014).

Sebagai sistem, desain pembelajaran merupakan pengembangan sistem pembelajaran dan sistem pelaksanaannya termasuk sarana serta prosedur untuk meningkatkan mutu belajar. Desain pembelajaran adalah an intellectual process to help teachers systematically learners needs and construct structures possibilities to responsively addres those needs (Cahyani, de Courcy, \& Barnett, 2018). Mendesain pelajaran bukanlah suatu pekerjaan yang dilakukan secara tiba-tiba, bukan pula suatu perencanaan tanpa posedur sistematis, melainkan harus merujuk pada model-model desain yang memeiliki karakteristik yang jelas. Bagaimanapun bentuk dan modelnya suatu desain pembelajaran, karakteristik utama dapat diklasifikasikan kedalam enam bagian yakni; 1) student centered, 2) goal oriented, 3) focuses on meaningful performance, 4) assumes outcomes can be measured in a realible and valid way, 5) enperical, iteratif, and self correction, and 6) a team offort. 
Seiring permasalahan di atas sebagaimana fenomena yang ditemukan dan terjadi di MTs Subulussalam Kayuagung bahwa guru terkhusus guru bahasa Inggris dalam menyampaikan materi di kelas kurang memperatikan perangkat pembelajaran yang telah disusunnya. Guru bahasa Inggris di MTs Subulussalam Kayuagung telah menyusun dan membuat rencana pelaksanaan pembelajaran berdasarkan silabus, namun dalam penyusunan tersebut tidak terlihat adanya penggunaan media dan terdapat kemiripan di setiap pertemuan. Hal ini tentunya berpengaruh pada saat proses pembelajaran dikelas menjadi kurang terarah dan tidak fokus. Pembelajaran yang terjadi tidak berdasarkan rencana pelaksanaan pembelajaran yang telah disusun, sehingga proses evaluasi juga tidak mengarah sesuai dengan tujuan pembelajaran. Disamping itu, guru bahasa Inggris di MTs Subulussalam Kayuagung dalam proses pembelajaran belum terlihatdalam memanfaatkan atau menggunaan media pembelajaran. Rencana pelaksanaan pembelajaran adalah suatu hal yang tidak dapat ditawar bagi searang pendidik karena hal tersebut adalah wajib dibuat atau disusun oleh pendidik. Untuk menghasilkan perangkat pembelajaran yang dapat menciptakan pembelajaran yang aktif, interaktif, inspiratif, menyenangkan, efisien, serta memotivasi siswa tersebut haruslah disusun suatu pengembangan dan model pembelajaran dengan memperhatikan kebutuhan siswa, memuat hal yang berkaitan langsung dengan aktivitas pembelajaran sebagai upaya pencapaian dan penguasaan kompetensi siswa.

Pengembangan perangkat pembelajaran yang sesuai dengan materi yang diajarkan sangatlah diperlukan, karena hasil belajar siswa merupakan salah satu indikasi dari tersampaikannya informasi serta berhasilnya tujuan instruksional dalam proses pembelajaran. Dalam Permendikbud No. 65 Tahun 2013 tentang Standar Proses Pendidikan Dasar dan Menengah disebutkan bahwa penyusunan perangkat pembelajaran merupakan bagian dari perencanaan pembelajaran. Perencanaan pembelajaran dirancang dalam bentuk silabus dan rencana pelaksanaan pembelajaran yang mengacu pada standar isi. Selain itu, dalam perencanaan pembelajaran juga dilakukan penyiapan media dan sumber belajar, perangkat penilaian, dan skenario pembelajaran.

Media pembelajaran merupakan segala sesuatu yang dapat menyampaikan dan menyalurkan pesan dari sumber secara terencana sehingga tercipta lingkungan belajar yang kondusif dimana penerimanya dapat melakukan proses belajar secara efisien dan efektif (Munadi, 2013). Media merupakan sesuatu yang bersifat meyakinkan pesan dan dapat merangsang pikiran, perasaan, dan kemauan siswa sehingga dapat mendorong terjadinya proses pembelajaran untuk mencapai tujuan pembelajaran (Anam, 2015).

Sebagainama hasil penelitian (Darllis, Farida, \& Miaz, 2021) tentang pengembangan desain pembelajaran model ASSURE di Sekolah Dasar menunjukkan bahwa desain pembelajaran yang dikembangkan memenuhi aspek keefektifan dilihat dari aktivitas peserta didik; sikap peserta didik; pengetahuan peserta didik yang melampaui KKM; dan keterampilan peserta didik. Desain pembelajaran yang dikembangkan juga memiliki karakteristik: praktis dalam penggunaan, penggunaan bahasanya jelas, logis, dan sistematis (Darllis et al., 2021).

Mengingat pentingnya keberadaan rencana pelaksanaan pembelajaran, maka harus direncanakan atau didesain dengan matang oleh seorang guru (Robian, Abdurahmansyah, \& Falahudin, 2021). Dari berbagai jenis desain pembelajaran yang telah berkembang sampai saat ini salah satu desain tersebut adalah desain pembelajaran model ADDIE. Desain pembelajaran model Analisis Desain Develop Implementasi Evaluasi (ADDIE) ini dipilih dalam penelitian pengembangan ini karena pembelajaran model Analisis Desain Develop Implementasi Evaluasi (ADDIE) memiliki tahapan-tahapan yang mudah diaplikasikan dan dilihat sesuai dengan pengembangan pembelajaran yang akan diterapkan dapat meningkatkan hasil belajar siswa (Garjita, Arthana, \& Sindu, 2017). 
Untuk itu peneliti tertarik melakukan pengembangan desain pembelajaran model ADDIE mata pelajaran bahasa Inggris di MTs Subulussalam Kayuagung.

Penelitian pengembangan ini bertujuan untuk menghasilkan rencana pelaksanaan pembelajaran model Analisis Desain Develop Implementasi Evaluasi (ADDIE) mata pelajaran bahasa Inggris yang teruji validitas, praktikalitas, dan efektifitasnya yang memiliki dampak pada hasil belajar Bahasa Inggris siswa di MTs Subulussalam Kayuagung.

\section{Metode Penelitian}

Penelitian dan pengembangan adalah suatu proses atau langakah-langkah untuk mengembangkan suatu produk baru atau menyempurnakan produk yang telah ada yang dapat dipertanggung jawabkan (Sugiyono, 2013). Menurut (Sugiyono, 2013) Metode penelitian dan pengembangan adalah metode penelitian yang digunakan untuk menghasilkan produk tertentu, dan menguji keefektifan produk tersebut. Produk tersebut dapat berupa materi ajar, modul, media, instrumen evaluasi, atau model perkuliahan. Dalam penelitian ini produk yang akan dikembangkan berupa prangkat pembelajaran mata pelajaran Bahasa Inggris yaitu rencana pelaksanaan pembelajaran yang nantinya digunakan di MTs Subulussalam Kayuagung OKI sebagai desain pembelajaran model ADDIE yang teruji validitas, praktikalitas, dan efektifitasnya. Penelitian dan pengembangan perangkat pembelajaran yang baik, maka diperlukan model pengembangan yang baik pula (Murtikusuma, 2015).

Tahap formative evaluation meliputi self evaluation, expert review, one-to-one, small group dan field test. Adapun alur desain formatif evaluation menurut (Tessmer, 1998 dalam Zulkardi, 2006) dapat dilihat pada gambar sebagai berikut:

Low resistance to revision $\longrightarrow$ High resistance to revision

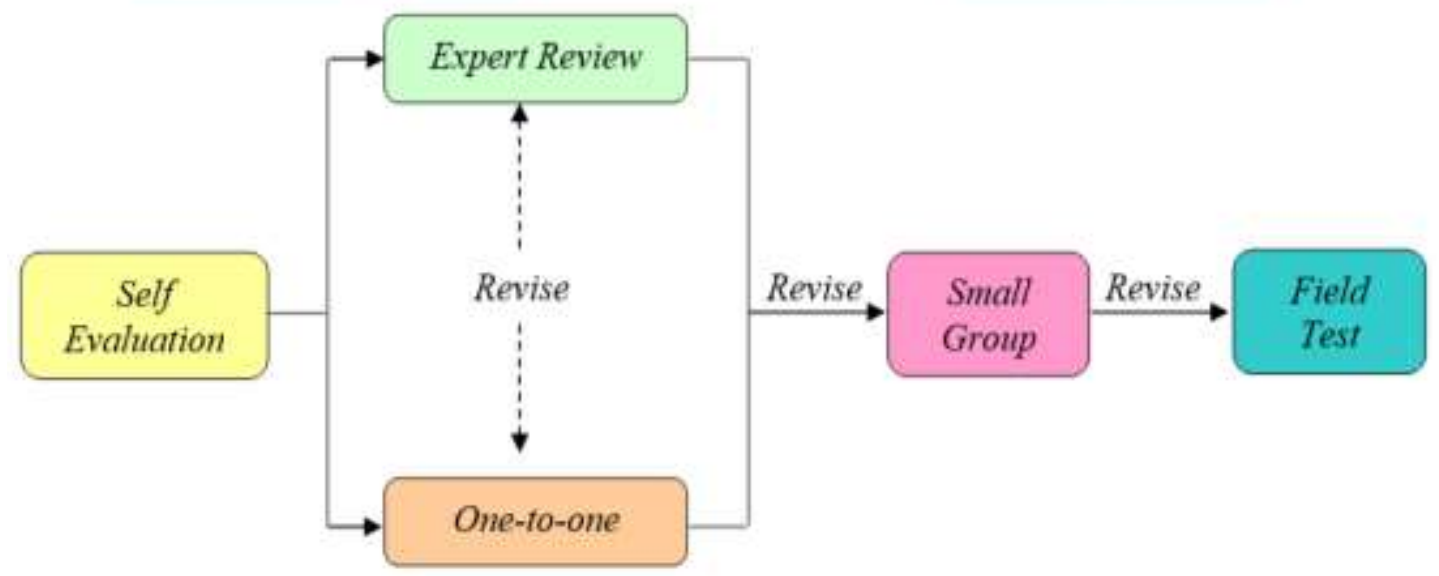

Gambar 1. Alur Desain Formatif Evaluation

Adapun langkah-langkah yang akan dilakukan dalam pengembangan desain pembelajaran dalam penelitian ini, yaitu sebagai berikut:

1) Self Evaluation

a. Tahap Analisis. Pada tahap ini, peneliti melakukan analisis materi pokok bahasan untuk menyesuaikan dengan kompetensi dasarnya, mengobservasi siswa yang 
dijadikan sebagai sampel, dan melakukan prosedur kerjasama untuk mendukung terlaksananya penelitian ini.

b. Tahap Desain. Pada tahap ini, peneliti melakukan perancangan perangkat pembelajaran dengan mengikuli langkah-langkah pengembangan model Analisis Desain Develop Implementasi Evaluasi (ADDIE). Pertama, peneliti mendesain perangkat pembelajaran berupa rencana pelaksanaan pembelajaran dan lembar kerja siswa, soal tes hasil belajar, lembar observasi aktivitas belajar siswa, dan menyusun angket respon siswa.

2) Prototyping (validasi, evaluasi, dan revisi)

a. Expert reviewdanone-to-one

Sebelum hasil prototype pertama diujicobakan, terlebih dahulu perangkat pembelajaran berupa rencana pelaksanaan pembelajaran dan lembar kerja siswa tersebut dilakukan uji validasi dengan tenaga ahli (expert review). Dari uji validasi oleh pakar tersebut akan diketahui kekurangan dan kelemahan, maka dilakukan revisi atau perbaikan. Peneliti menganalisis hasil validasi berupa saransaran dan masukan untuk dijadikan dasar dalam merevisi perangkat pembelajaran dan lembar kerja siswa mulai dari materi atau isi, segi media, maupun desain pembelajarannya.

Hasil tersebut setelah dianggap valid berdasarkan para ahli (expert review), selanjutnya dilakukan ujicoba pada siswa yaitu one-to-one. One-to-one yang digunakan adalah siswa kelas VIII.A MTs Subulussalam Kayuagung, pada oneto-one tersebut diberikan pembelajaran menggunakan desain pembelajaran yang peneliti kembangkan. Selama pembelajaran siswa tersebut diobservasi dan diminta megisi angket. Hasil dari expert review dan one-to-one dijadikan sebagai bahan untuk revisi ke prototype kedua.

\section{b. Small Group}

Berdasarkan hasil validasi expert dan one-to-one pada prototype pertama, maka dilakukan revisi desain prototype pertama yang nantinya akan menghasilkan prototype kedua. Hasil prototype kedua selanjutnya diujicobakan pada kelompok kecil (small group). Small Group dalam penelitian ini adalah siswa kelas VIII.A MTs Subulussalam Kayuagung. Peneliti sekaligus guru pada kelas tersebut melakukan kegiatan pembelajaran selama satu kali pertemuan dengan menggunakan perangkat pembelajaran yang telah dikembangkan dalam prototype kedua. Selama proses pembelajaran berlangsung, peneliti mengobservasi aktivitas siswa dengan menggunakan lembar observasi yang telah disusun dan pada akhir pembelajaran kepada small group diminta untuk memberikan komentar terhadap perangkat pembelajaran yang digunakan. Berdasarkan penilaian produk tersebut maka produk direvisi yang merupakan prototype ketiga. 


\section{Pelajaran Bahasa Inggris}

3) Field Test

Produk yang telah direvisi berdasarkan saran dari expert, one-to-one, dan hasil uji coba pada small group selanjutnya digunakan pada subjek penelitian yang sebenarnya atau field test. Produk yang diberikan pada field test merupakan produk yang telah memenuhi standar validitas, kepraktisan dan keefektifan yang artinya memiliki efek potensial terhadap hasil belajar siswa. Pengumpulan data yang digunakan dalam penelitian ini ada 3 , yaitu :

a) Observasi. Observasi digunakan untuk melihat keaktifan belajar siswa selama pembelajaran menggunakan hasil desain pembelajaran model ADDIE. Observasi dilakukan pada saat uji one-to-one dan pada small group, dan pada subjek penelitian yang sebenarnya (field test).

b) Angket. Angket digunakan untuk melihat tanggapan siswa terhadap hasil desain pembelajaran yang telah dikembangkan.Angket diberikan pada saat uji one-to-one dan pada small group, dan pada subjek penelitian yang sebenarnya (field test).

c) Tes Hasil Belajar. Tes hasil belajar digunakan untuk mengetahui hasil belajar siswa setelah melalui proses pembelajaran bahasa Inggris dengan menggunakan hasil desain pembelajaran model ADDIE. Tes diberikan pada one-to-one, pada small group, dan pada subjek penelitian yang sebenarnya (field test).

Berdasarkan data yang telah terkumpul dilakukan analisis; dari hasil observasi yang diperoleh dihitung perindikator, dengan cara menentukan besarnya frekwensi masing-masing aktivitas berdasarkan lembar observasi, kemudian menghitung persentasenya tentang keaktifan siswa menggunakan rumus:

$$
\mathrm{P}=\frac{\mathrm{F}}{\mathrm{N}} \times 100 \%
$$

\section{Keterangan:}

$\mathrm{P} \quad$ : Presentase aktivitas

F : Banyaknya aktivitas

N : Jumlah aktivitas keseluruhan (Indarti, 2008).

Hasil persentase observasi selanjutnya dibuat interval menjadi selang kategori berdasarkan skor maksimum dan minimum sebagai berikut:

Tabel 2. Kategori Keaktifan

\begin{tabular}{cc}
\hline Nilai Angket & Kategori \\
\hline $81-100$ & Sangat aktif \\
\hline $61-80$ & Aktif \\
\hline $41-60$ & Cukup aktif \\
\hline $21-40$ & Kurang aktif \\
\hline $0-20$ & Tidak aktif \\
\hline
\end{tabular}

Sumber: Modifikasi 


\section{Volume 1, Nomor 12, Desember 2021 p-ISSN 2774-7018; e-ISSN 2774-700X}

Hasil angket yang diberikan kepada responden untuk mengetahui respon siswa terhadap produk yang dihasilkan. Setelah data terkumpul, dihitung dengan menggunakan rumus sebagai berikut:

$$
N_{i}=\frac{X_{i}}{X_{m a k}} \times 100
$$

$$
\text { Keterangan : } \begin{array}{ll} 
& N_{i}=\text { Nilai Angket } \\
& X_{i}=\text { Jumlah skor yang diperoleh siswa } \\
& X_{m a k}=\text { Skor maksimum }
\end{array}
$$

Data-data yang diperoleh dilapangan dianalisis dengan menggunakan skala likert. Skala likert adalah alat pengumpul data untuk memperoleh gambaran kuantitatif aspek tertentu dari suatu barang atau sifat-sifat seseorang dalam bentuk skala yang sifatnya ordinal. Skala likert yang digunakan dikaterogikan dalam lima katagori berdasarkan modifikasi Nasoetion (2007), untuk kategori pertanyaan positif, yaitu : sangat baik (SB) dengan skor 5, baik (B) dengan skor 4, cukup (C) dengan skor 3, kurang baik (KB) dengan skor 2, dan tidak baik (TB) dengan skor 1. Sedangkan untuk kategori pertanyaan negatif, yaitu : tidak baik (TB) dengan skor 5, kurang baik (KB) dengan skor 4, cukup (C) dengan skor 3, baik (B) dengan skor 2, dan sangat baik (SB) dengan skor 1 .

Selanjutnya nilai angket dikonversikan ke dalam data kualitatif untuk menentukan pendapat siswa terhadap produk berupa desain pembelajaran yang dihasilkan. Selanjutnya hasil angket tersebut dituangkan dalam rentang kategori sebagai berikut:

Tabel 1. Kategori Respon siswa terhadap

Desain PembelajaranModel ADDIE

\begin{tabular}{cc}
\hline Nilai Angket & Kategori \\
\hline $81-100$ & Sangat baik \\
\hline $61-80$ & Baik \\
\hline $41-60$ & Cukup \\
\hline $21-40$ & Kurang baik \\
\hline $0-20$ & Buruk
\end{tabular}

Sumber: (Nasution, 2007)

Berdasarkan dari hasil tes siswa dianalisis untuk melihat tingkat pencapaian hasil belajar siswa dengan cara menjumlahkan skor semua jawaban. Ketuntasan hasil belajar siswa pada mata pelajaran bahasa Inggris diukur berdasarkan Kriteria Ketuntasan Minimal di MTs Subulussalam Kayuagung yaitu 70, sedangkan skor tes yang diperoleh masing-masing siswa dikonversikan menjadi nilai rentang $0-100$ dengan kategori sebagai berikut : 
Tabel 3. Kategori Hasil Belajar Siswa terhadap Desain Pembelajaran Model ADDIE

\begin{tabular}{cc}
\hline Skor & Kategori \\
\hline $86-100$ & Sangat Tinggi \\
\hline $71-85$ & Tinggi \\
\hline $56-70$ & Sedang \\
\hline $40-55$ & Rendah \\
\hline $0-39$ & Sangat Rendah \\
\hline
\end{tabular}

Sumber: Modifikasi.

\section{Hasil dan Pembahasan}

Penelitian pengembangan telah menghasilkan produk perangkat pembelajaran model Analisis Desain Develop Implementasi Evaluasi (ADDIE) yang teruji validitas, praktikalitas, dan efektifitasnya yaitu rencana pelaksanaan pembelajaran mata pelajaran bahasa Inggris kelas VIII MTs. Pengembangan desain pembelajaran diawalai dengan melakukan analisis terhadap siswa, rencana pelaksanaan pembelajaran, pemilihan materi hingga proses perancangan desain pembelajaran. Tahap awal yang dilakukan ini disebut tahap selfe evaluation. Peneliti selanjutnya melakukan penyusunan pengembangan desain pembelajaran menggunakan model Analisis Desain Develop Implementasi Evaluasi (ADDIE) dalam bentuk rencana pelaksanaan pembelajaran. Selanjutnya produk desain pembelajaran yang telah dikembangkan menggunakan model Analisis Desain Develop Implementasi Evaluasi (ADDIE) disebut prototype pertama. Langkah selanjutnya yaitu dilakukan validasi oleh pakar dan one to one, dimana validasi yang dilakukan oleh pakar terdiri dari ahli konten/isi, ahli bahasa, dan ahli media pembelajaran dengan mengunakan lembar penilaian validasi yang sudah disiapkan peneliti. Adapun hasil kesimpulan dari validasi ketiga pakar atau ahli bahwa desain pembelajaran yang telah dikembangkan menggunakan model Analisis Desain Develop Implementasi Evaluasi (ADDIE) dari segi isi, bahasa, dan media dalam kategori valid (Wulandari, Sudatha, \& Simamora, 2020).

Selain dilakukan uji validasi terhadap pakar atau ahli hasil desain pengembangan pembelajaran tersebut juga dilakukan uji validasi terhadap one to one yaitu dengan melibatkan sebanyak 3 (tiga) orang siswa dengan kondisi prestasi yang berbeda yaitu siswa pertama dengan prestasi akademik bagus atau pintar, siswa kedua dengan prestasi sedang, dan siswa ketiga dengan prestasi dibawah rata-rata. Uji coba ini dilakukan dengan tujuan untuk melihat kepraktisan dan petensial efek dari prototype pertama. Pelaksanaan pembelajaran dengan ketiga siswa tersebut diberikan materi hasil desain pembelajaran model Analisis Desain Develop Implementasi Evaluasi (ADDIE) (Cahyati, Syafdaningsih, \& Rukiyah, 2018). Selanjutnya diakhir pembelajaran ketiga siswa diminta menyelesaikan tes yang sudah dipersiapkan, dan diperoleh nilai rata-rata 81,67 dari masing-masing nilai siswa pertama 85, siswa kedua 85, dan siswa ketiga 75.

Berdasarkan hasil tes tersebut dapat disimpulkan bahwa prototype pertama mempunyai efek potensial terhadap hasil belajar siswa karena telah mencapai di atas kriteria ketuntasan minimum mata pelajaran bahasa Inggris yang ditetapkan di MTs Subulusalam Kayuagung. Disamping diminta mengerjakan tes ketiga siswa juga diminta mengisi angket untuk melihat tanggapan atau respon siswa terhadap desain pembelajaran yang telah dikembangkan. Dan dari hasil prototype pertama pada one to one didapatkan kategori nilai angket yaitu sangat baik. 
Berdasarkan hasil saran dan masukkan dari validator dan siswa bahwa desain pembelajaran prototype pertama dalam kategori valid dan praktis, baik dari segi materi, bahasa, dan media yaitu sesuai dengan kaidah pembuatan desain pembelajaran dengan mengikuti model pembelajaran yaitu model Analisis Desain Develop Implementasi Evaluasi (ADDIE) serta mempunyai efek yang potensial terhadap hasil belajar siswa (Agustina \& Adesti, 2019).

Berdasarkan hasil validasi oleh pakar materi, bahasa, dan media serta masukan dari one to one yaitu tiga orang siswa maka dilakukan perbaikan desain pengembangan pembelajaran dalam bentuk rencana pelaksanaan pembelajaran tahap ini disebut prototype kedua yang selanjutnya diujicobakan kepada small group yaitu siswa dengan kelompok kecil dari setiap kelompok terdiri dari 3 (tiga) orang siswa (Hala, 2015). Uji coba pada small group sama seperti pada uji cona pada one to one dengan diberikan pembelajaran bahasa inggris menggunakan hasil desain dan diakhir pembelajaran pada small group tersebut diminta menyelesaikan tes yang sudah dipersiapkan, dan diperoleh nilai rata-rata 84,67 dari masing-masing nilai siswa kelompok satu sebesar 88 , kelompok dua 79, dan kelompok tiga 87.

Berdasarkan hasil tes tersebut dapat disimpulkan bahwa prototype kedua mempunyai efek potensial terhadap hasil belajar siswa karena telah mencapai kriteria ketuntasan minimum mata pelajaran bahasa Inggris yang ditetapkan di MTs Subulusalam Kayuagung. Disamping diminta mengerjakan tes ketiga kelompok juga diminta mengisi angket untuk melihat tanggapan atau respon siswa terhadap desain pembelajaran yang telah dikembangkan, adapun kategori nilai angket yang diperoleh yaitu sangat baik.

Berdasarkan hasil validasi oleh pakar, one to one, dan small group dapat disimpulkan bahwa pengembangan desain pembelajaran model Analisis Desain Develop Implementasi Evaluasi (ADDIE) memiliki kesesuaian baik dari segi pemilihan materi, penggunaan bahasa, dan media. Selanjutnya hasil pengembangan desain pembelajaran model Analisis Desain Develop Implementasi Evaluasi (ADDIE) tersebut diberikan kesubjek penelitian yang sebenarnya yaitu siswa yang menjadi sampel dalam penelitian ini yaitu siswa kelas VIII.B MTs Subulussalam Kayuagung.

Maka secara umum disimpulkan bahwa desain pembelajaran model Analisis Desain Develop Implementasi Evaluasi (ADDIE) yang dikembangkan dari prototype pertama dan kedua sudah baik dan dalam kategori protytipe yang valid dan praktis. Setelah diperoleh prototype kedua yang valid, praktis, dan mempunyai dampak potential terhadap hasil belajar, selanjutnya diuji cobakan di lapangan pada subjek penelitian sebenarnya yaitu siswa kelas VIII.B MTs Subulussalam Kayuagung dengan jumlah 31 siswa.

Pembelajaran menggunakan hasil desain pembelajaran model Analisis Desain Develop Implementasi Evaluasi (ADDIE) ini dilakukan selama dua kali pertemuan. Pertemuam pertama dilakukan pada tanggal 02 Juni 2021 dan pertemuan kedua dilakukan pada tanggal 09 Juni 2021 dengan tema teks deskriptif lisan dan tulis, pendek dan sederhana, tentang orang, binatang, dan benda. Selama dilakukan pembelajaran, dilakukan observasi untuk melihat aktifitasnya, mengisi angket untuk melihat respon siswa, dan dilakukan evaluasi untuk melihat hasil belajaranya.

Analisis hasil observasi bahwa dari tujuh indikator keaktifan siswa selama pembelajaran diperoleh rata-rata yaitu pada pertemuan pertama sebesar $81,57 \%$, dan pada pertemuan kedua sebesar $87,14 \%$ sehingga rata-rata hasil observasi pada field test sebesar $84,35 \%$ dan dalam kategori sangat aktif (Aini, 2014). Analisis hasil angketrespon siswa terhadap desain produk yang dihasilkan, selama pembelajaran dalam dua kali pertemuan 
dapat dikatakan dalam kategori sangat baik, adapun dengan nilai rata-rata 90,74\% dari 10 indikator penilaian dan dari 31 siswa.

Analisis hasil belajar selama dua kali pertemuan terhadap sampel yang sebenarnya yaitu siswa MTs Subulussalam Kayuagung sebanyak 31 siswa. Adapun siswa diminta mengerjakan soal tes yang sudah disiapkan sebanyak 10 soal dengan tipe soal pilihan ganda dan essay. Dari hasil tes didapat nilai rata-rata 83 jauh di atas kriteria ketuntasan minimum mata pelajaran bahasa Inggris yang ditetapkan pada kelas VIII di MTs Subulussalam Kayuagung. Berdasarkan perolehan nilai tersebut terdapat $5(16,13 \%)$ siswa dengan kategori sangat tinggi, $18(58,06 \%)$ siswa dengan kategori tinggi, dan 8 $(25,81)$ siswa dengan kategori sedang. Tidak terdapat siswa dengan kategori rendah dan sangat rendah.

Sehingga peneliti dapat simpulkan bahwa hasil uji efektifitas desain pembelajaran model Analisis Desain Develop Implementasi Evaluasi (ADDIE) yang dikembangkan terhadap field test yang teruji validitas dan praktikalitasnya memiliki dampak terhadap aktifitas dan hasil belajar siswa, artinya desain pembelajaran model Analisis Desain Develop Implementasi Evaluasi (ADDIE) yang dikembangkan dalam kategori efektif.

\section{Kesimpulan}

Penelitian pengembangan ini menghasilkan produk perangkat pembelajaran model ADDIE yang teruji validitas, praktikalitas, dan efektifitasnya pada mata pelajaran bahasa Inggris kelas VIII MTs. Hasil uji validasi oleh pakar dari segi isi, bahasa, dan mediabahwa desain pembelajaran model Analisis Desain Develop Implementasi Evaluasi ADDIE) yang dikembangkan dalam kategori valid, oleh siswa secara one to one dan small group dalam kategori praktis, dan hasil terhadap field test memiliki dampak terhadap aktifitas dan hasil belajar siswa, artinya desain pembelajaran model Analisis Desain Develop Implementasi Evaluasi (ADDIE) yang dikembangkan dalam kategori efektif.

\section{Bibliografi.}

Agustina, Nora, \& Adesti, Anita. (2019). Pengembangan Modul Mata Kuliah Strategi Belajar dan Pembelajaran Pada FKIP-Universitas Baturaja. Syntax Literate; Jurnal Ilmiah Indonesia, 4(9), 83-93.

Aini, Khurrotul. (2014). Penerapan model pembelajaran inkuiri dengan hands on minds on activity untuk meningkatkan hasil belajar siswa pada materi pokok termokimia (implementation inquiry learning model with hands on minds on activity to improve student's achievments at thermochemistry). UNESA Journal of Chemical Education, $3(1)$.

Anam, Khoirul. (2015). Pengaruh media pembelajaran terhadap minat belajar siswa pada mata pelajaran pai di smp bani muqiman bangkalan. Tadarus: Jurnal Pendidikan Islam, 4(2), 1-17.

Cahyani, Hilda, de Courcy, Michele, \& Barnett, Jenny. (2018). Teachers' code-switching in bilingual classrooms: exploring pedagogical and sociocultural functions. International Journal of Bilingual Education and Bilingualism, 21(4), 465-479.

Cahyati, Nuri, Syafdaningsih, Syafdaningsih, \& Rukiyah, Rukiyah. (2018). Pengembangan Media Interaktif Dalam Pengenalan Kata Bermakna Pada Anak. Cakrawala Dini: Jurnal Pendidikan Anak Usia Dini, 9(2), 160-170.

Darllis, Neneng, Farida, F., \& Miaz, Yalvema. (2021). Pengembangan Desain Pembelajaran Model Assure Berbasis Problem Based Learning Menggunakan Komik di Sekolah Dasar. Jurnal Basicedu, 5(1), 334-342. 
Garjita, Dewa Ayu Andita Sari, Arthana, I. Ketut Resika, \& Sindu, I. Gede Partha. (2017). Pengembangan E-Modul Pada Mata Pelajaran Sistem Operasi Dengan Model Pembelajaran Problem Based Learning (Studi Kasus: Siswa Kelas X TKJ SMK Negeri 3 Singaraja). KARMAPATI (Kumpulan Artikel Mahasiswa Pendidikan Teknik Informatika), 6(1), 50-61.

Hala, Yusminah. (2015). Pengembangan perangkat pembelajaran biologi berbasis pendekatan saintifik pada konsep ekosistem bagi siswa sekolah menengah pertama. Journal of Educational Science and Technology (EST), 1(3).

Hanafy, Muh Sain. (2014). Konsep belajar dan pembelajaran. Lentera Pendidikan: Jurnal Ilmu Tarbiyah Dan Keguruan, 17(1), 66-79.

Munadi, Yudhi. (2013). Media pembelajaran sebuah pendekatan baru. Jakarta: Referensi. GP Press Group.

Murtikusuma, Randi Pratama. (2015). Pengembangan Perangkat Pembelajaran Matematika Model Problem-Based Learning Berbantuan Media Powerpoint Untuk Siswa Kelas XI SMK Materi Barisan dan Deret. Saintifika, 17(2).

Robian, Dian, Abdurahmansyah, Abdurahmansyah, \& Falahudin, Irham. (2021). Manajemen Pembelajaran Biologi Menggunakan Power Point. Studia Manageria, $3(1), 35-52$.

Sugiyono, Dr. (2013). Metode penelitian pendidikan pendekatan kuantitatif, kualitatif dan $R \& D$.

Wulandari, I. Gusti Ayu Agung Manik, Sudatha, I. Gde Wawan, \& Simamora, Alexander Hamonangan. (2020). Pengembangan Pembelajaran Blended Pada Mata Kuliah Ahara Yoga Semester II di IHDN Denpasar. Jurnal Edutech Undiksha, 8(1), 1-15.

Yaumi, Muhammad. (2017). Prinsip-prinsip desain pembelajaran: Disesuaikan dengan kurikulum 2013 edisi Kedua. Kencana.

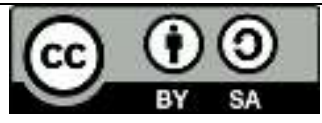

This work is licensed under a Creative Commons Attribution-ShareAlike 4.0 International License. 